Työ jatkuu yhä. Kummankin tapahtuman pohjalta on tekeillä ICOSin tieteellisen aikakauslehden Onoman teemanumero. Vierailevina päätoimittajina toimivat tapahtumien järjestäjinä toimineet Lasse Hämäläinen, Jaakko Raunamaa ja Johanna Virkkula. Numeroiden on määrä ilmestyä vuoden 2020 aikana.
LASSE HÄMÄLÄINEN etunimi.j.sukunimi@helsinki.fi JAAKKO RAUNAMAA etunimi.sukunimi@helsinki.fi

Lasse Hämäläinen valmistui filosofian tohtoriksi Helsingin yliopistosta suomen kielen alalta vuonna 2019. Jaakko Raunamaa on tohtorikoulutettavana Helsingin yliopistossa.

\title{
Yhteisymmärryksen rakentamisen monet keinot
}

\author{
Jenny Paananen: Yhteisymmärryksen \\ rakentaminen monikulttuurisilla \\ lääkärin vastaanotoilla. Turun yliopis- \\ ton julkaisuja - Annales Universitatis \\ Turkuensis, Sarja - Ser. C Osa - Tom. \\ 465. Scripta Lingua Fennica Edita. Turku: \\ Turun yliopisto 2019. ISBN 978-951-29-7556-3. \\ Johdanto 119 s., artikkelit 132 s. Luetta- \\ vissa verkossa osoitteessa http://urn.fi/ \\ URN:ISBN:978-951-29-7557-0.
}

Jenny Paanasen väitöskirjassa tarkastellaan sitä, miten monikulttuurisilla lääkärin vastaanotoilla rakennetaan yhteisymmärrystä lääkärin ja potilaan - ja osin myös tulkin - välillä. Tutkimuksen kohteena ovat sellaiset vastaanotot, joissa joko lääkäri tai potilas on ulkomaalaistaustainen. Kyseessä on artikkeliväitöskirja, joka sisältää viisi artikkelia ja niistä kirjoitetun laajahkon yhteenvedon. Tutkimus löytää paikkansa kahden vireän tutkimusalueen risteyksestä. Yhtäällä sekä Suomessa että maailmalla on tutkittu runsaasti lääkärin vastaanottojen ja muiden terveydenhuollon vuorovaikutustilanteiden rakentumista. Toisaalta myös kielellisesti ja kulttuurisesti epäsymmetrisiä vuorovaikutustilanteita on viime aikoina tarkasteltu paljon. Kyseisessä risteyskohdassa on kuitenkin ilmeinen tutkimusaukko, etenkin Suomen kontekstissa.

Väitöskirja on ajankohtainen ja yhteiskunnallisesti relevantti. Yhteenvedon toisessa luvussa Paananen käsitteleekin tutkimuksensa yhteiskunnallista kontekstia. Alaluvussa 2.1 hän pohtii väestörakenteen muutosta ja sen suhdetta terveydenhuollon asiakaskuntaan. Lisäksi hän tarkastelee aikaisempaa tutkimusta maahanmuuttajista terveydenhuollon asiakkaina. Alaluku 2.2 käsittelee maahanmuuttajien lisääntynyttä osuutta lääkärikunnassa ja aiheeseen liittyvää tutkimusta. Paananen kiinnittää huomiota siihen, miten sekä maahanmuuttajia asiakkaina että maahanmuuttajia lääkäreinä koskevassa tutkimuksessa on keskitytty ensisijaisesti heikosta kielitaidosta johtuviin ongelmiin. 
Kolmanneksi tutkimus liitetään potilaskeskeisen vuorovaikutuksen periaatteisiin. Paananen viittaa muun muassa Peräkylän ja Vehviläisen (2003) tutkimukseen, jossa osoitetaan, että vuorovaikutusideologioiden, kuten potilaskeskeisyyden ja aktuaalisen vuorovaikutuksen, suhde voi olla monenlainen ja että vuorovaikutustutkimuksen avulla voidaan tarkastella näitä ideologioita myös kriittisesti.

\section{Tavoitteet ja tutkimuskysymykset}

Väitöskirjan päätavoitteena on pureutua yhteisymmärryksen rakentamisen keinoihin monikulttuurisilla vastaanotoilla. Asetelma pohjautuu vahvasti ajatukseen vuorovaikutuksen resursseista, joiden avulla yhteisymmärrystä voidaan rakentaa ja ylläpitää. Paananen tekee tässä selvän eron tutkimuksiin, joissa on keskitytty vuorovaikutuksen ongelmiin.

Tutkimuskysymykset esitellään kahdella tavalla. Aluksi esitetään osatutkimusten tutkimuskysymykset, sen jälkeen yleiset tutkimuskysymykset, joihin kaikki artikkelit omalta osaltaan vastaavat. Yleisellä tasolla tutkimuksessa pyritään kuvaamaan niitä kielellisiä ja kehollisia resursseja, joiden avulla yhteisymmärrystä rakennetaan, sekä tarkastelemaan resurssien käytön suhdetta yhtäältä kieli- ja kulttuurieroihin, toisaalta lääkärin, potilaan ja tulkin institutionaalisiin rooleihin. Työssä on siis mielenkiintoinen asetelma, jossa kahdenlaiset epäsymmetriat, kieleen ja kulttuuriin liittyvät ja institutionaaliset, kohtaavat ja menevät osin myös ristiin.

Artikkeleista kolmessa ensimmäisessä tutkimuskohteena ovat erilaiset yhteisymmärryksen rakentamisen resurssit: 1) eleet (Paananen 2015), 2) lääkärin kysymykset (Paananen 2016) ja 3) lääkärin selitykset (Paananen 2017). Kahden muun artikkelin fokus on hieman erilainen: neljännessä (Paananen \& Majlesi 2018) tarkastellaan tulkkauksen roolia ja viidennessä (Paananen 2018) päätöksistä kes- kustelemista, erityisesti päätösaloitteita ja niihin vastaamista. Kokonaisuudessaan artikkeleista muodostuu kuitenkin monipuolinen kuva yhteistyön rakentamisen keinoista, ja ne vastaavat yleisempiin tutkimuskysymyksiin eri näkökulmista.

Tutkimuskysymyksiin vastaamisen osalta voi kuitenkin esittää kaksi kriittistä huomiota. Ensinnäkin osassa artikkeleista tutkimusasetelma ei ole aivan optimaalinen edellä mainittujen epäsymmetrioiden välisen suhteen tarkasteluun. Palaan tähän tarkemmin tulosten käsittelyn yhteydessä. Toiseksi, kieli- ja kulttuurierojen osalta työ keskittyy käytännössä enemmän kieleen kuin kulttuuriin.

\section{Teoreettinen viitekehys ja siihen liittyvä aikaisempi tutkimus}

Työn teoreettisena ja metodisena lähtökohtana on keskustelunanalyysi ja siihen pohjautuva vuorovaikutuslingvistiikka. Näitä suuntauksia esitellään yhteenvedon kolmannessa luvussa. Luvun lopussa on myös katsaus tutkimuksen kannalta relevanttiin keskustelunanalyyttiseen tutkimukseen lääkärin ja potilaan välisestä vuorovaikutuksesta, kielellisesti epäsymmetrisestä vuorovaikutuksesta sekä tulkatusta keskustelusta. Aikaisempaa tutkimusta esitellään näin ollen sekä toisessa että kolmannessa luvussa. Tämä ratkaisu on hiukan epäortodoksinen, mutta mielestäni kuitenkin toimiva. Toisessa luvussa esiteltävällä tutkimuksella lähinnä perustellaan väitöskirjan kontribuutioita ja sijoitetaan sitä yleisemmällä tasolla tieteen kenttään. Kolmannessa luvussa esiteltävä tutkimus taas toimii konkreettisena pohjana Paanasen omalle työlle; siihen viitataan toistuvasti aineiston analyysin yhteydessä.

Keskustelunanalyysia esitellessään Paananen ensin kuvailee sitä yleisellä tasolla ja sen jälkeen tarkemmin kahdesta näkökulmasta. Hän yhtäl̈lä pohtii sitä tapana tarkastella yhteisymmärryksen 
rakentamista (3.1.1) ja toisaalta esittelee vuorovaikutuksen perusjäsennykset ja liittää ne oman tutkimuksensa aineistoon ja tuloksiin (3.1.2). Alaluvussa 3.1.1 hän korostaa keskustelunanalyysin yhteyksiä muihin teorioihin ja tutkimustapoihin, ei niinkään sen erityisyyttä. Tässä hän liittyy samaan linjaan esimerkiksi Stevanovicin ja Lindholmin toimittaman (2016) käsikirjan kanssa. Tällainen ajattelutapa lienee muutenkin yleistynyt. Monissa aikaisemmissa keskustelunanalyysin esittelyissä on pikemminkin korostettu keskustelunanalyysin ainutlaatuisuutta suhteessa muihin teorioihin (esim. Hutchby \& Wooffitt 1998; ten Have 1999).

Vuorovaikutuslingvistiikan yhdistämisessä institutionaalisen vuorovaikutuksen tutkimukseen on omat haasteensa. $\mathrm{Ne}$ liittyvät erityisesti siihen, että kielen muotojen suhde toimintaan on kompleksinen, ja voi olla haastavaa pitää fokus yhtaikaa muodoissa ja institutionaalisessa toiminnassa. Paananen onnistuu minusta hyvin: hän lähtee ainakin pääosin liikkeelle institutionaaliselle tilanteelle ominaisista toiminnoista ja etenee niistä kohti kielellisiä rakenteita.

Kielellisten rakenteiden ohella Paananen tarkastelee tutkimuksessaan kaiken aikaa myös kehollisia resursseja. Kehollisuuden ja multimodaalisuuden teoreettinen pohdiskelu jää kuitenkin tutkimuksessa melko vähäiseksi.

\section{Aineisto ja menetelmät}

Tutkimuksen aineisto koostuu 48 videoidusta vastaanotosta, joista 27:ssä on ulkomaalaistaustainen lääkäri ja 21:ssä potilas. Kahdeksalla vastaanotolla on tulkki. Aineistoa on käytetty hieman eri tavoin eri artikkeleissa, mutta joka tapauksessa sitä on riittävästi ja siinä on myös riittävästi variaatiota tutkimuskysymysten näkökulmasta.

Tutkimuksen yhteenvedossa annetaan tarkka selonteko aineiston keräämisestä, eettisistä haasteista ja niihin vastaamisesta sekä siitä, millä tavoin aineistoa on tutkimuksessa käytetty, esimerkiksi miten aineistosta on kerätty tapauskokoelmia kutakin artikkelia varten. Paananen kertoo myös hyödyntäneensä etnografista havainnointia. Etnografinen panos jää työssä kuitenkin melko yleiselle tasolle; esimerkiksi tulosten esittelyssä se ei eksplisiittisesti näy.

\section{Tulokset}

Tutkimuksen tulokset käyvät ilmi artikkeleista. Yhteenvedossa keskeisimmät tulokset kootaan perusteellisesti ja pohditaan, mitä uutta artikkelit tuovat tieteelliseen keskusteluun. Käyn seuraavassa läpi tutkimustuloksia artikkeli artikkelilta. Käytän Paanasen itse lanseeraamia lyhyempiä otsikoita artikkeleihin viitatessani. Esitän myös joitakin kriittisiä huomioita.

Artikkelin "Eleet" (Paananen 2015) tarkoituksena on avata sitä, miten ikoniset ja deiktiset eleet toimivat yhteisymmärryksen rakentajina monikulttuurisilla lääkärin vastaanotoilla. Artikkelin päätuloksena on kolme eleiden käytön funktiota: ensiksi eleitä käytetään yhdessä kielen kanssa, ikään kuin samanlinjaisesti sen kanssa, toiseksi niillä peilataan puhekumppanin eleitä, ja kolmanneksi eleillä "korvataan" kielellisiä ilmauksia. Esimerkkien analyysi on pätevää, ja artikkeli tuo uutta tietoa eleiden käytöstä monikulttuurisissa tilanteissa ja siitä, miten eleet edistävät yhteisymmärryksen rakentumista. Väitöskirjan tavoitteiden näkökulmasta on kuitenkin hieman ongelmallista, että eleitä ei liitetä systemaattisesti mihinkään lääkärin vastaanoton toimintoihin eikä lääkärin ja potilaan tehtäviin vastaanotolla. Näin ollen artikkelin anti kolmannen tutkimuskysymyksen eli lääkärin ja potilaan roolien näkökulmasta jää melko ohueksi.

Artikkelissa "Kysymykset" (Paananen 2016) tarkastellaan lääkärin kysymysten uudelleenmuotoilua kahdesta näkö- 
kulmasta: Ensiksi pohditaan sitä, millaisissa vuorovaikutuskonteksteissa kysymyksiä muotoillaan uudestaan. Toiseksi eritellään sitä, millaisia keinoja lääkärit käyttävät tehdessään kysymyksistä ymmärrettävämpiä. Analyysi on kauttaaltaan vakuuttavaa, ja se valaisee myös kakkoskielisyyteen liittyviä tekijöitä lääkärin ja potilaan vuorovaikutuksessa. Olisin kuitenkin kaivannut systemaattista vertailevaa asetelmaa niiden tilanteiden välillä, joissa kakkoskielinen puhuja on yhtäältä potilaana, toisaalta lääkärinä. Nyt ei oikein syvällisesti päästä pureutumaan siihen mielenkiintoiseen jännitteeseen, jossa ammatillinen ja kielellinen epäsymmetria voivat olla joko linjassa tai sitten käydä vastakkain.

Artikkelissa "Selitykset" (Paananen 2017) tarkastellaan lääkärin selityksiä yhteisymmärrystä rakentavina toimintoina. Tarkasteltavana ovat vain sellaiset vastaanotot, joissa lääkärin äidinkieli on suomi. Tämä rajaus on mielestäni onnistunut. Asetelma on selkeä, ja se mahdollistaa kaksinkertaisen epäsymmetrian tutkimisen ja selittämisen tarkastelemisen lääkärin institutionaalisena tehtävänä. Vuorovaikutusanalyysissaan Paananen osoittaa, että lääkärit ottavat huomioon potilaan näkökulman ja että selitykset suuntautuvat vastaanoton tavoitteisiin. Tärkeää ei siis ole selittäminen sinänsä tai se, että potilaat ymmärtäisivät kaikki lääketieteelliset yksityiskohdat, vaan se, että heillä olisi vastaanoton kulun kannalta olennainen informaatio. Artikkelissa on myös vahva vuorovaikutuslingvistinen panos: se sisältää yksityiskohtaisen analyysin niistä kielellisistä ja kehollisista keinoista, joilla selittäminen tuotetaan. Analyysi on yksityiskohtaista ja oivaltavaa - kirjoittajalla on kyky tehdä havaintoja kielen hienovaraisista nyansseista. Myös kehollisen toiminnan analyysi on erinomaista. Vuorovaikutuslingvistinen näkökulma nivoutuu saumattomasti institutionaalisen vuorovaikutuksen analyysiin.
Artikkelissa "Tulkkaus" (Paananen \& Majlesi 2018) on aineistona kolme vastaanottoa, joissa on mukana tulkki, ja tavoitteena on tarkastella tulkin roolia yhteisymmärryksen rakentajana. Artikkelissa on kolme päälöydöstä: Ensiksi osoitetaan, että tulkki voi muokata lääkärin puhetta vastaanottajalle sopivaksi. Toiseksi tarkastellaan sitä, miten tulkki voi tuottaa minimipalautteita potilaan puheen aikana ja näin luoda potilaalle tilaa saattaa narratiivinsa loppuun. Kolmanneksi osoitetaan, miten tulkki peilaa sekä potilaan että lääkärin eleitä. Artikkeli tuo merkittävää uutta tietoa vähän tutkitusta teemasta. Tulokset kytketään potilaskeskeisyyden käsitteeseen. Potilaskeskeisyys käsitteenä ja institutionaalisena tavoitteena otetaan aika lailla annettuna, eikä siitä käytyä kriittistä keskustelua juurikaan käsitellä. Potilaskeskeisyys on kuitenkin artikkelin tavoitteiden kannalta toimiva käsite: artikkelissa osoitetaan, että tulkilla on keinoja edesauttaa potilaan osallistumista vuorovaikutukseen ja tässä mielessä lisätä potilaskeskeisyyttä.

Artikkelissa "Päätöksenteko" (Paananen 2018) on aineistona 36 vastaanottoa, joista puolessa ulkomaalaistaustainen on lääkäri ja puolessa taas potilas. Tämä asetelma mahdollistaa systemaattisen vertailun. Artikkelissa tarkastellaan päätöksentekosekvenssejä uni- ja bilateraalisen - yksipuolisen ja kahdenvälisen - päätöksenteon näkökulmasta. Yhtäältä eritellään päätösaloitteita niiden muotoilun ja niihin liittyvän deonttisen ja episteemisen auktoriteetin näkökulmasta, toisaalta tarkastellaan sitä, miten keskustelu etenee päätösaloitteiden jälkeen. Päätösaloitteet jaotellaan uni- ja bilateraalisuuden näkökulmasta jatkumolle pitkälti tukeutuen niiden muotoon. Tämä on pääosin toimiva ratkaisu. Joissakin kohdissa vaikuttaa minusta kuitenkin siltä, että on hiukan kaavamaisesti seurattu lausuman muotoa. Tässä suhteessa voi nostaa esiin esimerkiksi kategorian "lääkäri velvoit- 
taa". Siihen on otettu sellaiset tapaukset, joissa käytetään deonttista modaaliverbiä. Näissä tapauksissa kuitenkin käytetään pääosin nollapersoonaa ja toiminta, johon velvoitetaan, näyttäisi osin olevan sellaista, jonka suorittajana on terveydenhuoltoinstituutio. Onko tällöin kyse siitä, että lääkäri varsinaisesti velvoittaa (potilasta), vai ilmaiseeko hän pikemminkin jonkin institutionaalisen velvoitteen? Kokonaisuudessaan artikkeli antaa kuitenkin hyvän kuvan lääkärin päätösaloitteiden kirjosta ja onnistuu löytämään myös joitakin eroja äidinkielisten ja suomea toisena kielenä puhuvien lääkärien aloitteista.

\section{Lopuksi}

Tavallisimmin suomen kielen artikkeliväitöskirjoissa on neljä artikkelia. Jenny Paanasen väitöskirja on näin ollen varsin laaja. Laajuuden mukana työhön on tullut jonkun verran hajanaisuuttakin, mutta kaikki artikkelit tuottavat kuitenkin uutta tietoa väitöskirjan keskeisestä teemasta, yhteisymmärryksen rakentamisesta monikulttuurisilla lääkärin vastaanotoilla. Tutkimuksessa otetaan hienolla tavalla huomioon vuorovaikutuksen multimodaalisuus: yhteisymmärrystä rakennetaan sekä kielen että kehon avulla.

Johdannon pohdintaluvussa Paananen tuo myös hyvin esiin tutkimuksensa pedagogisen ja yhteiskunnallisen merkityksen. Pedagogiikan näkökulmasta on olennaista, että väitöskirjassa tuodaan usein varsin yleisten periaatteiden rinnalle myös yksityiskohtaista tietoa kielellisistä ja kehollisista keinoista, joilla yhteisymmärrystä voidaan edistää. Yhteiskunnallisen keskustelun näkökulmasta Paanasen resurssikeskeinen näkökulma on tervetullut. Vuorovaikutuksen ongelmista pitää totta kai puhua, mutta yhtä tärkeää on kiinnittää huomiota siihen, mitä osataan, miten ongelmia ratkaistaan ja yhteisymmärrystä rakennetaan onnistuneesti.

\section{ESA LEHTINEN \\ etunimi.t.sukunimi@jyu.fi}

Kirjottaja on nykysuomen professori Jyväskylän yliopistossa. Hän toimi Paanasen vastaväittäjänä.

\section{Lähteet}

Have, Paul ten 1999: Doing conversation analysis. A practical guide. Lontoo: Sage.

Hutchi, IAn - Wooffitt, Robin 1998. Conversation analysis. Principles, practices and applications. Cambridge: Polity Press.

PaAnanen, Jenny 2015: Kuinka eleet helpottavat yhteisymmärrystä? Ikoniset ja deiktiset eleet monikulttuurisilla lääkärin vastaanotoilla. - Puhe ja kieli 35 s. 73-95.

— 2016: Kuinka lääkärit korjaavat kysymyksiään? Kysymysten uudelleenmuotoilu monikulttuurisilla lääkärin vastaanotoilla. - Virittäjä 120 s. 552-579.

— 2017: Kuinka lääkärit selittävät asiantuntijainformaatiota? Selittäminen vuorovaikutuksellisena, kielellisenä ja kehollisena toimintana monikulttuurisilla vastaanotoilla. - Puhe ja kieli $37 \mathrm{~s}$. 119-144.

— 2018: Päätöksenteko monikulttuurisilla lääkärin vastaanotoilla. - Sosiaalilääketieteellinen aikakauslehti 55 s. 287-308.

PaAnanen, Jenny - Majlesi, Ali Reza 2018: Patient-centered interaction in interpreted primary care consultations. - Journal of Pragmatics 138 s. 98-118.

PerÄkylä, Anssi - Vehviläinen, SANNA 2003: Conversation analysis and professional stocks of interactional knowledge. - Discourse \& Society $14 \mathrm{~s}$. 727-750.

Stevanovic, Melisa - Lindholm, Camilla (toim.) 2016: Keskustelunanalyysi. Kuinka tutkia sosiaalista toimintaa ja vuorovaikutusta. Tampere: Vastapaino. 